\title{
Choosing Chemistry at Different Education and Career Stages: Chemists, Chemical Engineers, and Teachers
}

\author{
Gabriella Shwartz $^{1}$ D $\cdot$ Or Shav-Artza ${ }^{1}$ D $\cdot$ Yehudit Judy Dori $^{1,2}$ (D)
}

Accepted: 11 March 2021 / Published online: 25 March 2021

(c) The Author(s) 2021

\begin{abstract}
In response to the realization that qualified applicants' choice of a career in chemistry is declining, we investigated the factors involved in chemistry and chemical education career choice. Building on the social cognitive theory (SCT) and the social cognitive career theory (SCCT), this research examines the personal, environmental, and behavioral factors influencing the chemistry-related profession choice of 55 chemists, 18 chemical engineers, and 72 chemistry teachers. Research participants also suggest ways to encourage students to major in chemistry during high school and pursue a chemistry-related career. Results showed that high school serves as a significant turning point of future career choices. Self-efficacy in the task-oriented and chemistry learning aspects are the driving forces of choosing a chemistry career. We also shed light on the importance of enhancing students' choice in chemistry-related career via quality educational programs. The study contribution lies in examining all three aspects of career choice in the SCCT. We have applied this framework specifically in chemistry, but the identified factors can be applied to other STEM domains. Practically, we provide recommendations for different stakeholders on how to overcome the shortage of skilled chemistry professionals.
\end{abstract}

Keywords Career choice $\cdot$ Chemistry education $\cdot$ Social cognitive career theory

\section{Introduction}

Chemistry connects the physical sciences with life sciences and applied sciences. As chemistry is vital for the economy, it is important to encourage adolescents to choose a chemistry-related career (Solano et al., 2011; Avargil, Kohen, \& Dori, 2020).

Choosing science, technology, engineering, and mathematics (STEM) career in general and chemistry in particular is declining, and this hinders sustainable economic development worldwide (Diekman \& Benson-Greenwald, 2018; Salonen et al., 2018; Simon et al., 2017).

The shortage starts with chemistry teachers, who motivate their students to major in chemistry (Barnea, Dori, $\&$ Hofstein, 2010; Salta et al., 2012). The insufficient number of high school students who choose to major in

Gabriella Shwartz

gabbysh@technion.ac.il

1 Technion, Israel Institute of Technology, 3200003 Haifa, Israel

2 Samuel Neaman Institute, Technion City, 3200003 Haifa, Israel chemistry leads to fewer higher education graduates, resulting in an acute shortage of qualified, skilled chemists, and chemical engineers (Christensen \& Knezek, 2017; Smith $\&$ White, 2019). A broader research conducted by Avargil et al. (2020) mapped the distribution of choice in chemistry, other STEM, and non-STEM disciplines among high school graduates, freshmen, and bachelor graduates during 1992-2015 (see Appendix 1). Results showed that high school years are crucial for adolescents in their pathway towards career choice in chemistry: The percentage of high school chemistry graduates that completed a chemistry bachelor's degree is 3.8 times higher than high school graduates from other STEM subjects (Dori, Shwartz, \& ShavArtza 2020). Therefore, identifying factors that affect career choice provides educators, industrialists, and other stakeholders with key points to emphasize boosting a chemistry career choice among high-quality candidates and skilled, knowledgeable chemistry professionals. Although there is a growing number of studies investigating how to promote careers in STEM in general (Mishkin, Wengrowicz, Dori, \& Dori, 2016; Nugent et al., 2015; van Tuijl \& van Der Molen, 2016) and chemistry in particular (D'Andola, 2016; Grunert \& Bodner, 2011), much of this research is focused 
on a specific group of participants and on personal, environmental, and behavioral themes that are specialized to a chemistry-related career choice. However, these themes are usually not domain specific and can shade lights on career choice of other STEM domains.

Our research strives to understand the career choice factors of chemistry teachers (CTs), and of chemists and chemical engineers, collectively called chemical industry professionals (CIs). These two groups were selected due to the following reasons: (a) the teachers meet high school students at the entry point of their career choice decision; (b) the chemists are already employed in chemistry professions, and we seek to help evolve and retain them; and (c) they represent two chemistry-related occupations - education and industry.

The research questions are as follows:

(1) What are the most influential categories in the personal, environmental, and behavioral themes that affect chemistry teachers and chemists in choosing their careers?

(2) How can we encourage students to major in chemistry during high school and later to choose a chemistry-related career?

We have identified a variety of factors influencing career choice in chemistry at two career paths: industry and education. Results of our study might provide policymakers and chemistry educators with recommendations for encouraging high school students to major in chemistry and undergraduate students to choose and retain chemistry-related careers.

\section{Conceptual Framework: Social Cognitive Career Theory}

Career choice studies evolved into investigating more complex career paths. The social cognitive career theory (SCCT) is based on the social cognitive theory (SCT; Bandura, 1986) and has been applied to practice and research in expanding the STEM pipeline (Smith \& White, 2019). We chose SCCT as the theoretical basis for explaining how and why career and academic interests mature, develop, and turned into action (Lent et al., 2002). It relies on the interconnection between personal attributes, such as self-efficacy, outcome expectancy, and goals with environmental, and behavioral themes that influence one's aspirations towards a career choice as illustrated in Fig. 1 (Lent et al., 1994, 2002).

\section{Factors in the Personal Theme}

Focusing on the personal theme, self-efficacy represents the self-belief in one's ability to organize and complete the actions needed to reach a required outcome (Bandura, 1986). It was found to be an important predictor of career interest, performance, and persistence during education and subsequently in a career (Blotnicky et al., 2018; Kelly \& Hatcher, 2013; Sahin et al., 2017). Self-efficacy can change by active learning, feedback from others, and observation of role models' success (Caspi et al., 2019; Newell et al., 2015; Young et al., 2017). Outcome expectations are personal beliefs about the results of specific actions performed to pursue a career. SCCT asserts that people develop an interest in a career when they are confident of their skills and abilities. This interest drives the development of goals and actions, which promote career selection (Lent et al., 1994). In a context of high school, exposure to STEM develops interest and motivation in STEM, leading to majoring in STEM and a STEM career choice (Bottia et al., 2018; Lent \& Brown 2006; Wang, 2013).

\section{Factors in the Environmental Theme}

Lent, Brown, and Hackett $(2000,2002)$ presented two types of contextual factors within the environment theme: (a) distal contextual factors, which emerge when individuals learn and interact with their own cultural and social expectations, and (b) proximal contextual factors, which are directly related to career choice concerns, e.g., significant role models and job opportunities. Contextual factors, be they distal or proximal, may support an individual's choice or become a barrier towards pursuing a career. The need for support refers mainly to proximal factors. For
Fig. 1 The SCCT model based on Lent and colleagues (2002, 2003)

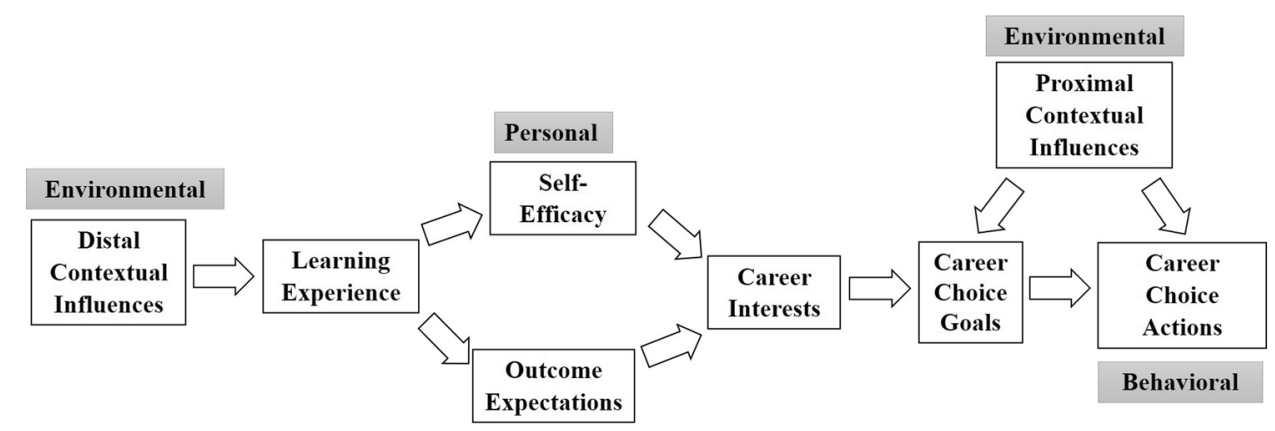


example, it is easier to overcome a financial barrier by getting financial help than to overcome being raised in a low socioeconomic environment. Yet, even if there are distal contextual limitations, support can be found, such as parents who encourage their children to study and support them. Studies investigating the environmental and behavioral influence on career choice relating to social, parental, and school contextual factors revealed that parents and teachers serve as sources of advice and as motivators that influence one's self-efficacy (Alexander et al., 2011; Sahin et al., 2015; Sha et al., 2016). Science teachers' encouragement strongly influence students' academic performance and majoring in STEM (Dorph et al., 2018; Reinhold et al., 2018).

Environmental support, such as emotional support and career advising, are positively correlated with career outcome expectations and self-efficacy (Ziebell, 2010). For example, early exposure to science may influence students' future STEM choice and performance (Dabney et al., 2013; Yasin \& Yueying, 2017). This exposure increases their STEM career interest, self-efficacy, and outcome expectations (Blotnicky et al., 2018; Nugent et al., 2015).

\section{The Behavioral Theme in the SCCT}

The SCCT connects the personal and the environmental themes to the third one-the behavior theme. The behavior theme is expressed in one's career choice and overt behavior, such as seizing opportunities and overcoming barriers that result from self-efficacy and/or career-related interest. People will take actions to achieve their goals or subsequent performance attainments (e.g., successes, failures), provide valuable feedback that can strengthen or weaken self-efficacy and outcome expectations, and ultimately, help to revise or confirm choices (Lent et al., 2002; 2003). Table 1 summarizes the categories in the personal, environmental, and behavioral themes along with specific examples from the science or chemistry fields.

\section{Chemistry Career Choice in Industry and Education}

Studying chemistry enables careers in industry, medicine, food, pharmacology, education, and academia. Skills developed while studying chemistry can be applied in many other areas (Lechleiter, 2013). In previous study, we found that some of the factors that influence the career choices of CIs are different from the factors that influence the career choices of CTs ( Avergil et al., 2020).

\section{Factors Affecting Cl Career Choice}

Focusing on chemistry career choice, several factors were identified as influencing one's choice. Within the encouraging factors:

- Students' choice was driven mainly by their interest (personal theme) in chemistry (Ogunde et al., 2017).

- Achievements are also an important aspect to consider, as students who continue to study chemistry at the university do so because they think they can be good scientists (Hazari et al., 2010). The interest and high self-efficacy of these students foster developing their goals which results in a STEM career choice as presented in Fig. 1.

- Proximal influence was also documented as science teachers' encouragement strongly influences students' academic performance and majoring in STEM (Dorph et al., 2018; Hazari et al., 2010; Reinhold et al., 2018). As emphasized in the SCCT, proximal influence might affect one's behavior in his/her career choice.

Addressing the discouraging factors in choosing a chemistry career, we found the following:

- The nature of the chemistry domain is central—students consider chemistry to be difficult (Salta et al., 2012); it is intangible, hard to grasp, and requires great investment, patience, and perseverance (Cleaves, 2005; Kafetzopoulos et al., 2006). This contextual factor as described in Salta

Table 1 Summary of themes and categories in the SCCT

\begin{tabular}{|c|c|c|c|}
\hline Theme & Category & Description & $\begin{array}{l}\text { Examples from the literature on science or chem- } \\
\text { istry career-choice }\end{array}$ \\
\hline \multirow[t]{3}{*}{ Personal } & Self-efficacy & $\begin{array}{l}\text { The self-belief in one's ability to complete an } \\
\text { action }\end{array}$ & \multirow{3}{*}{$\begin{array}{l}\text { *One's belief in his/her ability to be good scien- } \\
\text { tists (Hazari et al., 2010) } \\
\text { *High achievements in chemistry enhance out- } \\
\text { come expectations (Ogunde et al., 2017) }\end{array}$} \\
\hline & Outcome expectations & $\begin{array}{l}\text { Personal beliefs about the results of specific } \\
\text { actions performed }\end{array}$ & \\
\hline & Career interest & One's curiosity in a specific field & \\
\hline \multirow[t]{2}{*}{ Environmental } & Distal contextual influences & $\begin{array}{l}\text { Address the interaction with their one's cultural } \\
\text { and social expectations }\end{array}$ & $\begin{array}{l}\text { Stigmas regarding chemistry-related professions } \\
\text { (Salta et al., 2012) }\end{array}$ \\
\hline & Proximal contextual factors & Directly related to career choice concerns & Lack of job opportunities (Dalgety \& Coll, 2004) \\
\hline Behavioral & Career choice actions & $\begin{array}{l}\text { Seek to gain entry into a particular academic } \\
\text { major or a professional job }\end{array}$ & $\begin{array}{l}\text { Overcoming barriers and choosing a science } \\
\text { related career (Lent et al., 2002) }\end{array}$ \\
\hline
\end{tabular}


and colleagues (2012) serves as a barrier to chemistry learning that influences students' decision not to engage in a chemistry related-career.

- Because chemistry has an inferior status in education, where little teaching time is allocated, and in society, it is considered as providing limited employment opportunities, with requirements that have not changed over the years (Dalgety \& Coll, 2004; Salta et al., 2012). This proximal contextual factor of lacking job opportunities inhibits the behavioral theme by reducing the chances to choose a chemistry-related career.

\section{Factors Affecting CT Career Choice}

Moving towards the choice in chemistry education, general, and not domain specific aspects were identified-intrinsic, extrinsic, and altruistic factors (Kass \& Miller, 2018; Richardson \& Watt, 2016). Extrinsic motivation relates mainly to environmental aspects, such as family-friendly working conditions, security and flexibility of employment, status and prestige, convenient working hours and vacations, or leverage on other jobs. Intrinsic motivation, which addresses the personal theme, includes natural abilities and prepositions that describe natural affinity for teaching, high self-efficacy, enjoyment, a sense of duty and responsibility associated with the role of a teacher, leadership abilities, academic skills, and an intellectual challenge (Heinz, 2015). Altruistic motivations include the desire to help children, pursue meaningful work, influence students, and become their role model, and the passion to share acquired knowledge and become an agent of social change for the benefit of the community (Friedman, 2016; Kass \& Miller, 2018).

\section{Setting and Participants}

In Israel, ${ }^{1}$ chemical industry encompasses petrochemicals, pharmaceuticals, commodity chemicals, plastics, and specialty chemicals, including flavors, fragrances, and detergents. Chemistry is first introduced to students in middle school, where it is integrated into the general science curriculum. Middle school science teachers have different educational backgrounds, not specifically chemistry, so students are taught chemistry by non-chemistry teachers. Changes in high school science curriculum have contributed to the decline of interest in chemistry. Graduating from high school, there are several academic tracks to study chemistry and pursue higher degrees in chemistry. There is a decline in the number of chemistry teachers and industry professions: during 2008-2016, the percentage of chemistry graduates

\footnotetext{
${ }^{1} \mathrm{http}: / /$ www.economy.gov.il/Industry/Industry_and_Environment/ Chemical_Industry/Pages/Chemical_Industry.aspx\#GovXParagraphTitle3
}

decreased by $60 \%$ (Avergil et al., 2020; Central Bureau of Statistics, 2018). The number of chemistry teachers during 1998-2015 decreased by $18 \%$, and the number of schools in which chemistry is taught has decreased from 43 to $16 \%$ (Central Bureau of Statistics, 2018).

To understand the personal, environmental, and behavioral themes affecting chemistry career choice and provide recommendations for choosing a chemistry career, we focused on 143 participants. Table 3 in Appendix 2 presents the distribution of the participants by gender, sector, and seniority. Most of the high school chemistry teachers $(N=72)$ had over 10 years of experience. Chemists $(N=55)$ and chemical engineers $(N=18)$ worked in industry or research centers, and half were senior.

\section{Research Methodology}

The study applied a mixed-methods approach (Shekhar et al., 2019) in two phases. In line with Creswell (2006), the study was carried out in an explanatory sequential way, with quantitative data obtained in the first phase from the Chemistry Career Choice (C3) questionnaire (Avergil et al., 2020). The qualitative part in the second phase comprised of interviews. The theoretical SCCT framework provided the personal, environmental, and behavioral themes for choosing a chemistry-related career.

\section{Research Tools and Data Analysis}

First Phase: Administering Questionnaires. Being part of a broader study, the Chemistry Career Choice (C3) questionnaire was developed and its validity and reliability were tested, yielding six factors with high internal consistency ( Avergil et al., 2020). We administered electronically the C3 questionnaire to both CTs and CIs. ${ }^{2}$ The first part of the questionnaire included demographic and personal data. The second part consisted of 34 statements on a Likert-type scale (1-5) in the personal and environmental themes dealing with choosing a chemistry-related career. Table 2 contains the categories and their description with an exemplary item from the $\mathrm{C} 3$ questionnaire. Analysis of the quantitative data included analysis of variance, Pearson correlation, and repeated measures one-way ANOVA with Wilks' Lambda test.

Second Phase: Conducting Interviews. The goal of conducting the interviews was to allow participants to provide detailed answers while sharing their life story of their career

\footnotetext{
${ }^{2}$ Out of 73 chemists who participated in this study, 66 responded to the questionnaire and 10 were interviewed (three interviewees also responded to the questionnaire).
} 
Table 2 Themes, categories, and items in the C3 questionnaire (Avergil et al., 2020)

\begin{tabular}{|c|c|c|c|}
\hline Theme & Category & Description & Exemplary item from the questionnaire \\
\hline \multirow[t]{3}{*}{ Personal } & $\begin{array}{l}\text { Self-efficacy-Chemistry learning and } \\
\text { teaching }\end{array}$ & $\begin{array}{l}\text { One's sense of efficacy in learning and } \\
\text { teaching chemistry }\end{array}$ & $\begin{array}{l}\text { I can understand research processes in } \\
\text { chemistry }\end{array}$ \\
\hline & Self-efficacy-task-oriented & Persistence in achieving tasks and goals & $\begin{array}{l}\text { I have the ability to deal with challenging } \\
\text { tasks in my work }\end{array}$ \\
\hline & Self-confidence in one's career & $\begin{array}{l}\text { One's sense of efficacy in developing a } \\
\text { chemistry related career }\end{array}$ & $\begin{array}{l}\text { I have tensions regarding my ability to } \\
\text { pursue a career in chemistry }\end{array}$ \\
\hline \multirow[t]{3}{*}{ Environmental } & $\begin{array}{l}\text { Extrinsic motivation-rewards/status/ } \\
\text { prestige }\end{array}$ & $\begin{array}{l}\text { Attitudes, stigmas, salary aspects regard- } \\
\text { ing the chemistry profession }\end{array}$ & $\begin{array}{l}\text { Working in chemistry allows high social } \\
\text { status }\end{array}$ \\
\hline & Influence of teachers/lecturers & $\begin{array}{l}\text { Teacher quality, encouraging choice of } \\
\text { chemistry profession }\end{array}$ & $\begin{array}{l}\text { My teacher/lecturer encouraged me to } \\
\text { read advance papers in chemistry }\end{array}$ \\
\hline & Family and friends & $\begin{array}{l}\text { Influence of family and close friends on } \\
\text { choosing chemistry as a profession }\end{array}$ & $\begin{array}{l}\text { I am interested in a job that will consider } \\
\text { my family status }\end{array}$ \\
\hline
\end{tabular}

path choice. Analysis of the questionnaire provided us with an answer as to which factor was the most influential to CTs and CIs in their career choice, while the analysis of the interview provided insight into how this factor influenced one's choice (Dori et al., 2020). The first part of the interview protocol included general questions regarding the participant's educational background, former job occupation, current place of occupation, seniority, and job description. The second part of interview protocol included general questions regarding participants' career choice. For example, see the following questions: Describe the reasons that led you to choose a chemistry-related career; Are you satisfied with your chemistry-related career choice? Please address this question in terms of salary, colleagues, and work environment. In interviews of this kind, the main questions are formulated in advance, but the order of their presentation is not predetermined, and there is a possibility for new questions to be raised in the context of the interview, sometimes leading to spontaneous questions and answers (Patton, 1990). Indeed, based on the interviewee's answer, more specific questions in the personal, environmental, and behavioral themes, which were not addressed in the questionnaire, were presented. In the personal theme, following are several questions aimed at understanding the participant's sense of self-efficacy: What were the educational and occupational milestones, including formative experiences and events you observed and experienced?

Questions in the environmental theme addressed the influence of different role models, such as teachers or lecturers whom the participants had encountered and might had influenced their career choice: Did you encounter personalities that influenced your career choice? We also asked about the reactions they received from others (family members/teachers/colleagues) when they informed them of their decision to pursue a career in chemistry. Questions in the behavioral theme allowed them to provide a reflection on their career decision actions, barriers, and support they received along the way: Considering your academic and career history, if you could have done anything differently, what would that be? Lastly, they were asked to suggest ways to encourage students to major in chemistry during high school and later to choose a chemistry-related career.

The interviews lasted $1 \mathrm{~h}$ and were conducted with chemists $(N=6)$, chemical engineers $(N=4)$, and chemistry teachers $(N=10)$. All interviews were audio-recorded, transcribed, and qualitatively analyzed, maintaining confidentiality and anonymity.

Guided by the SCCT, we employed flexible variations, open coding, and selective coding to analyze the qualitative data (Flick, 2018; Roulston, 2008). Three experts performed the open coding, which began with breaking down the collected statements into small segments that were classified into the three major themes-personal, environmental, and behavioral, and helped determine corresponding categories within each theme. For axial coding, the experts held in-depth discussions about assigning each statement to the proper theme and category. A similar process was applied when analyzing data referring to participants' recommendations regarding how to encourage students to major in chemistry during high school and later to choose a chemistryrelated career; the smaller interview statements focused on a single idea emphasizing a specific type of recommendation. A discussion among researchers was held about attributing each statement to the proper recommendation until an agreement was reached. For both set of statements, the inter-judge agreement data for encoding statements based on the list of categories as measured using Kappa reliability was 0.92 .

In the second analysis stage, we analyzed the qualitative data with additional descriptive, quantitative data in line with recent trends on analyzing texts using thematic analysis also currently referred to as data mining. Studies on occupational attainment have used text mining (Ignatow \& Mihalcea, 2017) or thematic analysis for studies in 
science education (Tal \& Alkaher, 2010). This process aims at finding main themes of document counting of words and from that count analyze the document. The importance of factors identified via the close-ended questions in the questionnaires was established also through the analysis of the frequency of repetition and consistency of factors identified, and their relative importance. Trustworthiness was kept by the engagement of the authors in this research area and was strengthen via triangulation of the two research tools (Creswell, 2006; Denzin \& Lincoln, 2000). We calculated for each group the average number of statements in each theme and category. The average number of statements was calculated by dividing the total number of statements in each theme or category by the number of participants that were interviewed-10 in each group. The total number of statements in the CI group was $N=376$, and the CI personal theme included 111 statements.

\section{Results}

\section{Factors in the Personal Theme That Affect CT and CI Career Choices}

Using data collected from the $\mathrm{C} 3$ questionnaire, Fig. 2 shows the themes and categories that affect CTs and CIs to choose a chemistry-related career. The personal theme was found to influence the career choice significantly more than the environmental theme $(t(69)=12.65$, $p<0.001)$ for both CTs and CIs $(t(15)=4.00, p<0.001$; $t(65)=13.10 .00, p<0.001)$.

Two-way ANOVA analyses of variance with repeated measures were performed in order to compare between the categories within each of the personal and environmental themes, and the interaction with the type of participant group. For the personal theme, we found that the two groups perceived the influence of each category on their career choice differently, $F(2,133)=3.14, p<0.05$, $\eta^{2}=0.05$. Simple main effect tests with Bonferroni adjustment revealed that both groups perceived SEtask-oriented as the most influential category on their career choice, and the Self-confidence in one's career as the least influential. However, while CTs perceived the task-oriented category as influential at the same level as the SE-scientific/chemistry learning and teaching category, CIs perceived this category as less influential than the task-oriented category.

Figure 3 shows the average number of statements in each theme and category for both groups. Green and blue colors represent statements of CTs and CIs, respectively, made during the interviews. The light color indicates a small number of statements, and dark color-a high number. The personal theme is the most influential on CT career choice, confirming the quantitative results. Teachers talked about their SE in chemistry teaching and learning and the task-oriented aspects. They expressed
Fig. 2 Personal and environmental themes influencing $\mathrm{CT}(N=72)$ and $\mathrm{CI}(N=66)$ chemistry career choice

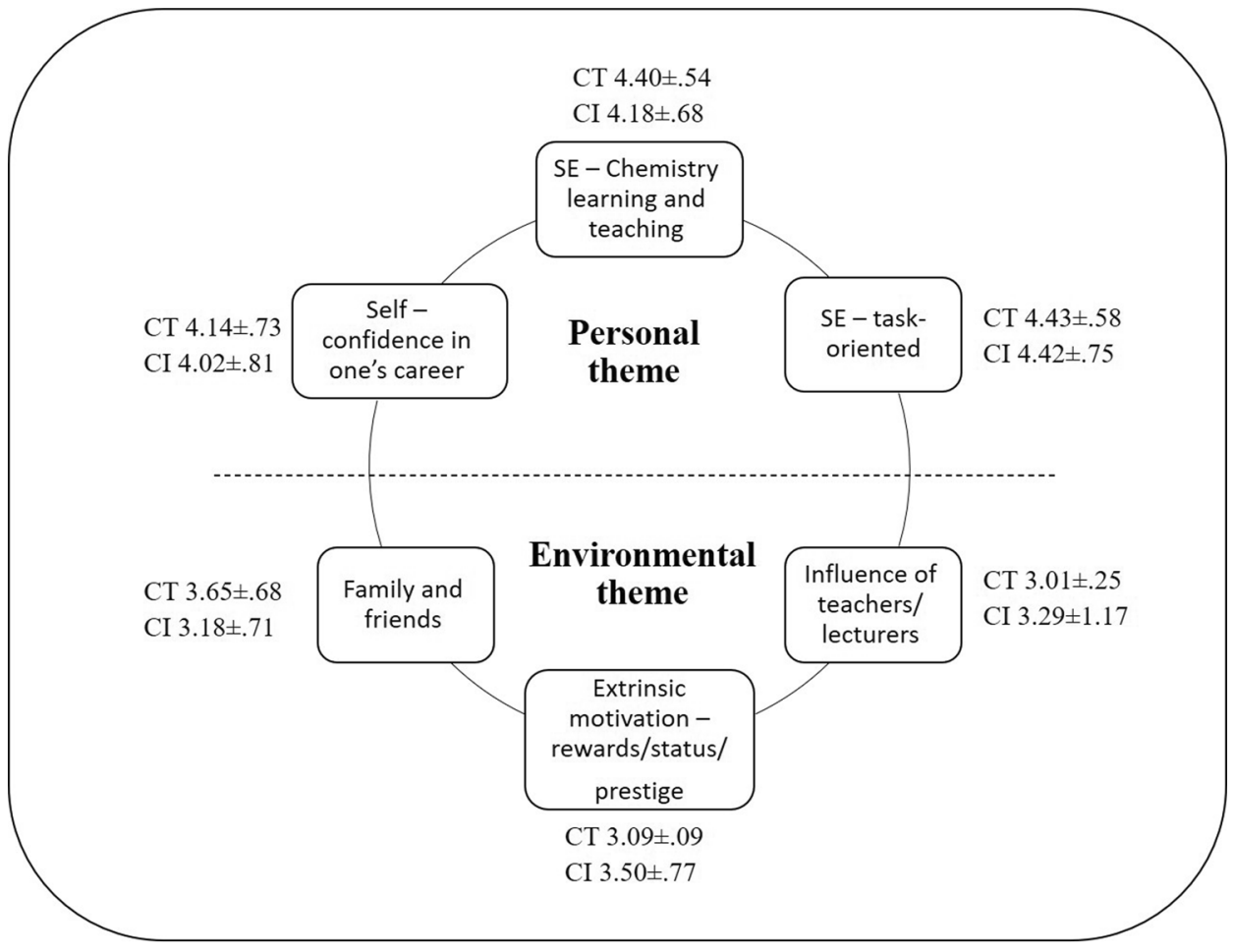

Springer 


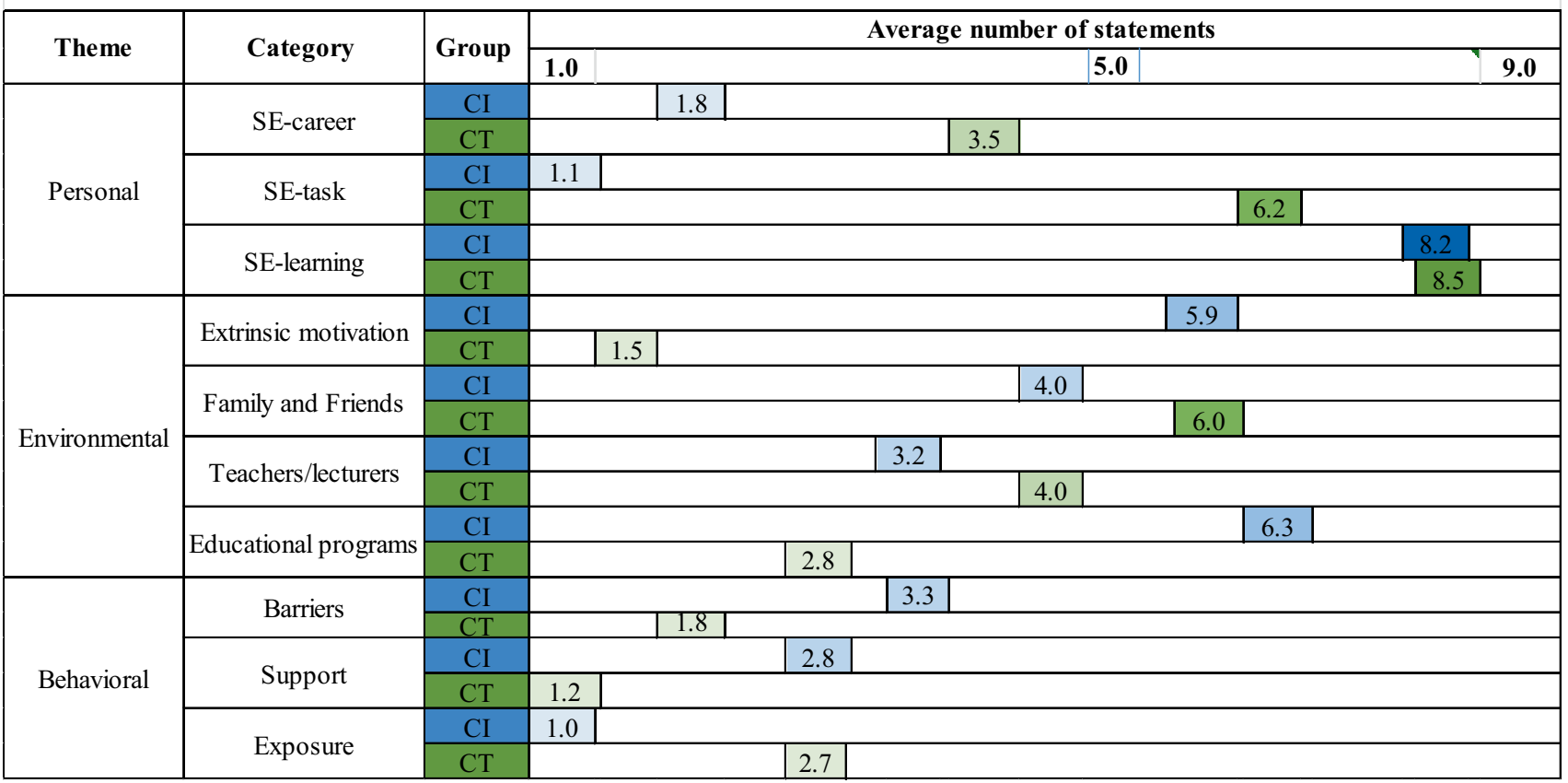

Fig. 3 Average number of statements in each theme and category among CT and CI

their high sense of mission and intrinsic motivation when describing why they chose teaching as their career; one teacher said: "I always felt I had the ability to succeed as a teacher because I know how to explain the microscopic level in chemistry in various ways" [CT3]. Another teacher talked about the task-oriented aspect of being a teacher: "Being a teacher is challenging but that's what motivated me in the first place-preparing my students for the matriculation exam, managing the classroom and being innovative in my pedagogy" [CT7]. CIs described their everyday work as being intensive, in the laboratory or plant, but still expressed high motivation to accomplish their goals and be successful in their work: "Every day, I find myself navigating through implementing experiments, analyzing new data, reading innovative research, and dealing with a lot of bureaucracy. I know how to manage my priorities correctly so I will be successful as a manager and show results" [CI4].

Teachers also expressed high confidence in their choice and their ability to balance teaching with family life. CIs talked about their success in high school and university as enhancing their self-efficacy in chemistry: "I was always good in understanding the microscopic world of chemistry, and therefore I was always successful in it. During high school and university, I got high grades in chemistry courses, and in my work, I am able to investigate aspects in chemistry that interest and challenge me" [CI8].

\section{Factors in the Environmental Theme That Affect CT and $\mathrm{Cl}$ Career Choices}

For the environmental theme, we found that the two groups perceived the influence of each category on their career choice differently, $F(2,133)=20.14, p<0.001, \eta^{2}=0.23$. CTs perceived the family and friends as the most influential factor, while CIs perceived the Extrinsic motivationrewards/status/prestige as most influential (see Fig. 2).

Analyzing participants' career pathways through the environmental theme has revealed a new category-Quality of educational program (see Fig. 3), which refers to the curriculum, and educational activities students were exposed to in high school and university. This new category of the environmental theme was found to be the most influential in choosing a career among CIs along with extrinsic motivation. When talking about extrinsic motivation aspects, CIs mainly referred to the prestige of a chemistry career and the salary conditions. One CI talked about the salary and how it reflects on the status of the profession: "The salary is not as high as in high-tech, but it is respectable, and it is possible to move up to higher salaries over time. When the profession becomes prestigious, the salary will be rewarding" [CI1]. Another CI talked about the scholarships he had received, which enabled him to advance in his chemistry-related career. Compared to CTs, CIs were more concerned regarding the status of a chemistry career in the society and the working conditions, such as salary CIs gain. 
Fig. 4 Key elements for encouraging students to choose chemistry for their future career

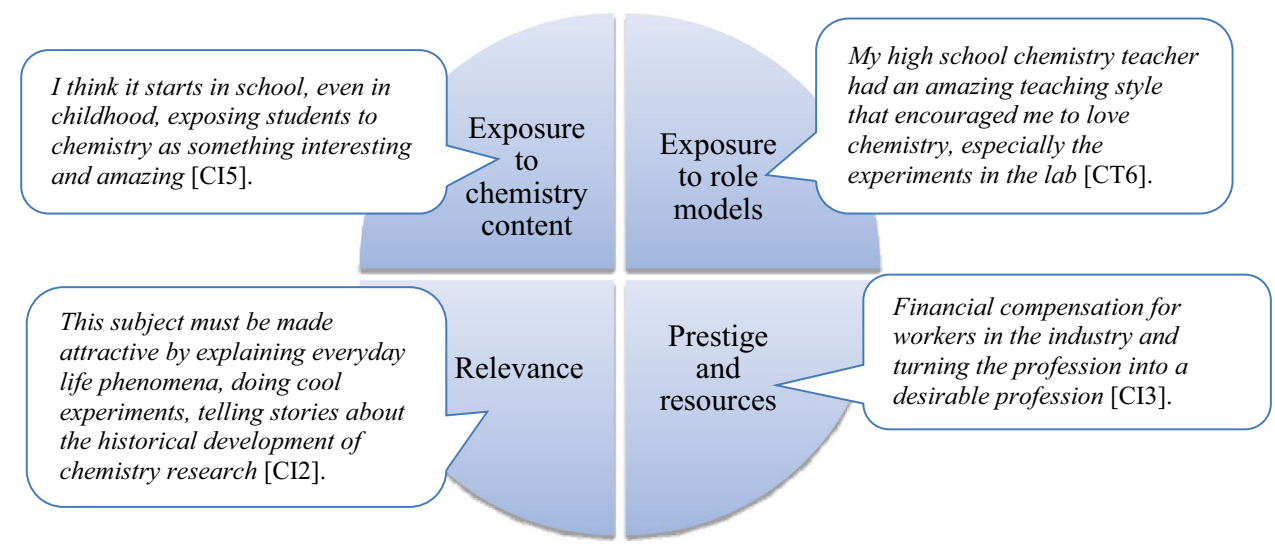

Regarding the educational programs that supported their career choice, one participant [CI5] reflected that being exposed to a lot of labs and courses related to the industry increased his passion to study chemistry and choose a chemistry-related career. Another CI reflected: "Compared to today's curriculum, when I studied chemistry, we not only learned chemistry but we also did chemistry, so the theory and practice were linked. Furthermore, I remember that our program included learning about the different industries in chemistry, and we even visited several of them. Seeing how the factory operated and what is the role of the chemists in this operation made me realize I want to be part of it" [CI3]. CIs highlighted the importance of the practical knowledge they had learned during high school that is implemented in industry: "I think that I would not have chosen a career in chemistry if I had not studied chemistry during my high school years. I revealed how interesting and complex chemistry is, connected to all aspects of life, and I succeeded in it ... Understanding the variety of chemistry-related professions made me realize I want to learn more about it" [CI2]. Family, friends, and chemistry teacher in high school were also mentioned in a positive way as supporting participants' decision to choose a chemistry-related career: "A significant role model in my life that led me to choose chemistry is my high school chemistry teacher, who made me curious about this field" [CI3].

\section{Factors in the Behavioral Theme That Affect CT and $\mathrm{Cl}$ Career Choices}

The interview added information also about the SCCT behavioral theme, which addresses choices, actions, or specific apparent behavior that influenced one's career choice before, during or after his/her decision-making process. We present three behavioral theme categories: (1) Exposure to science/chemistry learning and teaching at early stages in life; (2) barriers, obstacles, and limitations; and (3) getting support and career opportunities. CIs mentioned the barriers, obstacles, and limitations in their profession that influenced their career pathway: "The industry is changing and demanding, and I had to make a change in my chemistry career... These changes, although in the beginning they seemed to me as negative and challenging, enabled me to reassess my aspirations, my interest in the specific field I was in, and the working condition that were suitable for me" [CI4]. Another chemist noted: "When I felt my current position limited my progression in my chemistry career, I realized I had to make a change and consider other options to pursue my career ambitions" [CI8]. Barriers and limitations participants talked about empowered them to make a change and set the ground for their future progress and advancement in their profession.

CTs expressed their early age experiences and exposure to chemistry teaching in different educational contexts through their life: "Teaching science and chemistry were part of my life in every step. As a student, I was in a community service program that taught science to elementary students; I also worked at the technical education center in my city with children" [CT2].

The early exposure participants talked about is at two levels: (1) introducing the essence of chemistry content, connecting the macroscopic and microscopic levels, and (2) introducing the career opportunities, employment channels, work characteristics, and responsibilities. CIs emphasized the support and promotion opportunities, which enabled them to succeed and make new decisions in their career pathway. One participant said: "I had the privilege of being part of companies that are constantly innovating, which motivated me to advance and succeed in this profession" [CI9].

\section{Encouraging Students to Major and Choose Chemistry as Their Future Career}

We asked both groups how we can encourage students to major in chemistry during high school and choose a chemistry-related career. Figure 4 presents key elements 
that CTs and CIs perceive as important to increasing the number of students who choose to major in chemistry and work in a related field: (1) exposure to chemistry at different educational levels, (2) meeting with role models and hearing their inspirational life stories, (3) making chemistry relevant to everyday life experiences, and (4) raising awareness about stigmas and invest more in the prestige and resources in chemistry education. These elements included specific actions needed to be taken in two levels-students and chemistry professions: we need to increase students' internal motivation, curiosity, interest, involvement in the learning process, and shape their attitudes towards chemistry, as well as reshape the way chemistry is perceived by society as a profession.

\section{Exposure}

The first element, exposure, refers to exposing students to chemistry at different education levels, starting from elementary school. According to the CTs, middle school students are exposed mostly to physics and biology, with less time devoted to chemistry. As a result, students are not exposed to chemistry and do not know what it means; they think chemistry is difficult and/or boring and it will be difficult for them to succeed in it. One teacher shared: "I am not talking only from my experience as a teacher but also as a parent to a teenager who is studying general science in middle school; students are not exposed to cool and interesting experiments, and they don't understand the beauty and the connection of chemistry to everyday life. Moreover, they do not understand what they can do with chemistry later in their lives and what the relevant industries for a chemist are. When they come to my chemistry class in high school and I ask them what they had learned in chemistry during middle school and what chemistry symbolizes for them, the common answers are: covalent bond, atoms, molecules, ionic compounds - I agree with them that this is boring. When I show them a variety of pictures connected to chemistry, such as a car, lipstick or a medication, they do not see the chemistry there" [CT1]. CIs emphasized that the exposure will instill in student's curiosity, motivation, and interest in chemistry that may lead to majoring in chemistry in high school and at the university level.

\section{Role Models}

Another important aspect is exposing adolescents to rolemodels, which may help them see themselves as scientists or engineers, increase their motivation, and shape their attitudes towards a career in science. CTs suggested incorporating career education into the teaching sequence by incorporating life stories of role-models. CIs mentioned their teachers in high school as role models that inspired them to choose chemistry as an academic field and a career. They also suggested creating frameworks for scientists to visit schools and tell students about their academic career: "Students need to hear and learn about success stories and realize that these scientists and Nobel-prize chemists were chemistry students just like them. Relating to their life story, field of research, academic career, millstones they reached, and their challenges and successes will show them that it is possible to develop a career in chemistry" [CI2].

\section{Relevance}

With respect to Relevance, both groups emphasized the importance of connecting chemistry to everyday life experiences and learning in context. Teachers shared that integrating everyday life situations in their teaching triggers students' curiosity and involvement: "Recently, I taught my students oxidation and reduction reactions. We cleaned silver jewelries in the classroom as I was explaining them why the jewelry becomes black after a while and what the reaction that allows the coating to be removed is. Why am I telling you this? because from this point on, the students were so enthusiastic that every time they saw corrosion in their surroundings, they took a picture and sent it in the WhatsApp group of our classroom, explaining how we can prevent this process. They felt this was relevant to their everyday and were happy to understand what surrounds them and how they can contribute to prevent it. This is only one example of many" [CT4]. CIs noted that exposing students to the variety of chemical industries should be part of the curriculum, so students will learn "real-life" dilemmas, considerations and inquiry in the working field. They offered organizing more student visits to industry laboratories.

\section{Prestige and Resources}

Prestige and resources refer to raising awareness about stigmas and invest more in (a) advanced laboratories, (b) extracurricular educational programs that expose students to chemistry, and (c) raising salaries for chemical professionals. One CI emphasized: "In today's reality, chemistry should be advertised differently for it to reach more people so the perception of this profession will change. We should show our laboratories, new technologies and advanced equipment, as well as our young and enthusiastic scientists researching and contributing to the society with their ideas and innovations. We should organize science and chemistry camps for children and advertise chemistry" [CT9].

Participants indicated that there are still stigmas about scientists sitting alone in a lab, doing experiments by themselves, pouring smelly substances from one test tube to 
another: "People associate chemistry with bed smell, toxic and dangerous substances and a lonely scientist sitting in the laboratory. It is perceived as an old-fashion science and not as attractive as others. This perception must be changed to increase the number of people who choose the chemistry profession" [CT7]. Unfortunately, chemistry is perceived by students as less attractive and prestigious compared with other disciplines, such as physics or computer science.

\section{Discussion}

In response to the realization that qualified applicants' choice of a career in chemistry is declining, we investigated the factors involved in chemistry and chemical education career choice. This study uses the SCCT to analyze the factors that guide teacher's and chemistry professionals' career choice, and their suggestions for encouraging youth's pursuit of a chemistry-related career.

\section{Self-Efficacy as a Driving Force for Choosing a Chemistry-Related Career}

Focusing on the factors effecting CTs ad CIs to choose a chemistry-related career, self-efficacy (SE) beliefs were found to influence both groups. In SCCT, SE is central and is theorized to strongly influence one's career interest and choice. In the category of $S E$ - chemistry learning and teaching, CIs reflected upon their success and high grades in high school and university, and CTs emphasized their ability to explain and expose their students to the world of chemistry. The quantitative results showed that CIs felt less secure than CTs regarding learning chemistry. This can be explained by the fact that teachers are exposed to a variety of chemistry topics on a daily basis. They encourage their students to explore what interest them while providing information that is sometimes beyond the curriculum (Demirdöğen et al., 2016; Avergil et al., 2020). CTs are also involved in professional development that exposes them to different research processes, advanced methods in chemical industry and scientific articles. CIs' expertise is usually in their specific domain, so they feel less secure about their knowledge of chemistry in other topics.

For both groups $S E$-task-oriented was the most significant category, with no differences between the two groups. Although perceiving the teaching profession as challenging, CTs believe in their ability to navigate through different tasks, enhance students' chemical understanding, implement a variety of teaching methods, manage their classroom, and prepare their students for the matriculation exam. Moreover, they are enthusiastic about becoming teachers, describe teaching as a satisfying and interesting profession that meets their goals and ambitions, and enables them to influence and contribute to young people's lives, even though the financial reward is relatively low. CIs also expressed confidence in their ability to accomplish tasks and overcome challenges with the goal of being successful in their work in the laboratory or industry. Having high sense of SE that was shaped and nurtured over different points in the lives of CTs and CIs affected their academic and occupational behavior during adolescence and early adulthood. Their beliefs in their capability to cope with assignments in their job reduced the level of career barriers and motivated them to work towards their chosen career. As Fig. 1 shows, their high SE leads to the formation of their career choice goals and later turns into career choice actions (Kelly et al., 2013; Sahin et al., 2017). The category of SE task-oriented aspects, addressing the requirements of the profession itself, received less attention in other studies. Our results show that the combination of high sense of self-efficacy in chemistry knowledge along with feeling confident about the nature of the work, such as handling challenging tasks, proposing a course of action and meeting deadlines, are essential when choosing a career.

\section{High School and the Role of Significant Others in Pursuing Chemistry Teaching as a Future Career}

The role of society and high school in motivating CTs and CIs to peruse a chemistry-related career was reflected mainly through the environmental theme, specifically in the teachers and lecturer's category, and in the educational program category. Participants described their high school chemistry teachers as supportive and encouraging, enhancing their curiosity in and love of chemistry. High school curriculum was also mentioned as significant as providing the connection between theory, laboratory practice, and relevance to the industry. Majoring in chemistry during high school provided participants with the opportunity to experience active learning and succeeding in this discipline, which raised their sense of self-efficacy. Relating to the SCCT, these proximal contextual influences enhanced participants' self-efficacy and career interest, led to the development of their career choice goals, and resulted in choosing a chemistry-related career. These results are supported by the literature: significant others, such as teachers, and learning experiences during high school have a positive effect on pursuing it in university and later as a career (Alexander et al., 2011; Bottia et al., 2018; Reinhold et al., 2018).

\section{Enhancing Chemistry Career Knowledge via Quality Educational Programs}

Addressing the behavioral theme, chemistry teachers and industrialists emphasized the importance of Exposure to science/chemistry learning and teaching at early stages 
in life. They noted that early and significant exposure to chemistry might enhance students' understanding of what chemistry is and how it is connected to our life and to the labor market. CIs also expressed that realizing what the nature of a chemists' job is and what the relevant industries for them are encouraged them to choose a chemistry-related career. This result leads to a more in-depth discussion regarding the importance of prior chemistry career knowledge. Career knowledge is one's familiarity with a particular STEM career, for example, chemistry, and the understanding of the requirements and the set of responsibilities expected from him/her in their field of occupation (Blotnicky et al., 2018; Sharf, 1992). STEM career knowledge has been investigated to a lesser extent, although STEM career knowledge should get more attention (Blotnicky et al., 2018). The level of STEM career knowledge an individual directly affects one's intentions of pursuing a STEM career (Blotnicky et al., 2018; Nugent et al., 2015). Without adequate prior knowledge, students might dismiss a STEM-based career path as a potential option. As emphasized by several teachers, when students start high school, they do not know what chemistry is, what chemists do, and where they work. Equipping students with chemistry career knowledge in an early stage, as recommended by participants, might facilitate their understanding regarding the nature of chemistry work, potentially leading them to choosing a chemistry-related career. CIs emphasized that the educational programs they were exposed to influenced their career choice by simulating the life of a chemists in the laboratory and visiting different factories that provided a glimpse into their possible future. One way to expose students to chemistry career knowledge is by improving educational programs so they would expose students to chemistry careers and the nature of chemistry work. As our participants recommended, replacing the non-attractive theoretical teaching approach and the emphasis on memorizing with labs, inquiry, and learning in context might raise students' interest in chemistry (Baram-Tsabari \& Yarden, 2005; Dori et al., 2020; Magwilang, 2016; Avergil et al., 2020). Our data support the need to integrate chemistry career knowledge into the curriculum in a variety of ways: connecting chemistry to everyday life, meeting with role model scientists and industrialists and explaining the nature of their work, and visiting a variety of chemistry-focused industries.

\section{The Public Image of Chemistry}

CIs indicated Extrinsic motivation-rewards/status/prestige in the environmental theme as influential on their career choice. In their recommendations for encouraging students to major and choose chemistry as their future career, salary conditions and the way chemistry is perceived by students and society were raised-all are related to rewards and prestige in the extrinsic motivation category. These aspects were also identified by Salta et al., (2012) who investigated factors that influence students not to pursue a chemistryrelated career. They noted that when people hear the word "chemistry," they immediately think about environmental pollution caused by the by-products of chemical industry and the misuse of chemicals. Furthermore, the term "chemophobia" refers to the fear of chemicals and chemistry (Kafetzopoulos et al., 2006). Students also have images of scientists and chemists as "being in white coats," using "test tubes in labs," chemists as "hard working," "nerdy," "boring," etc. (Cleaves, 2005; Dalgety \& Coll, 2004). Such images might be highlighted by the media and influence students' decision-making process in their career path (Kniveton,

Fig. 5 A model connecting SCCT to interviewees' recommendations for fostering choice of chemistry as a major and a career

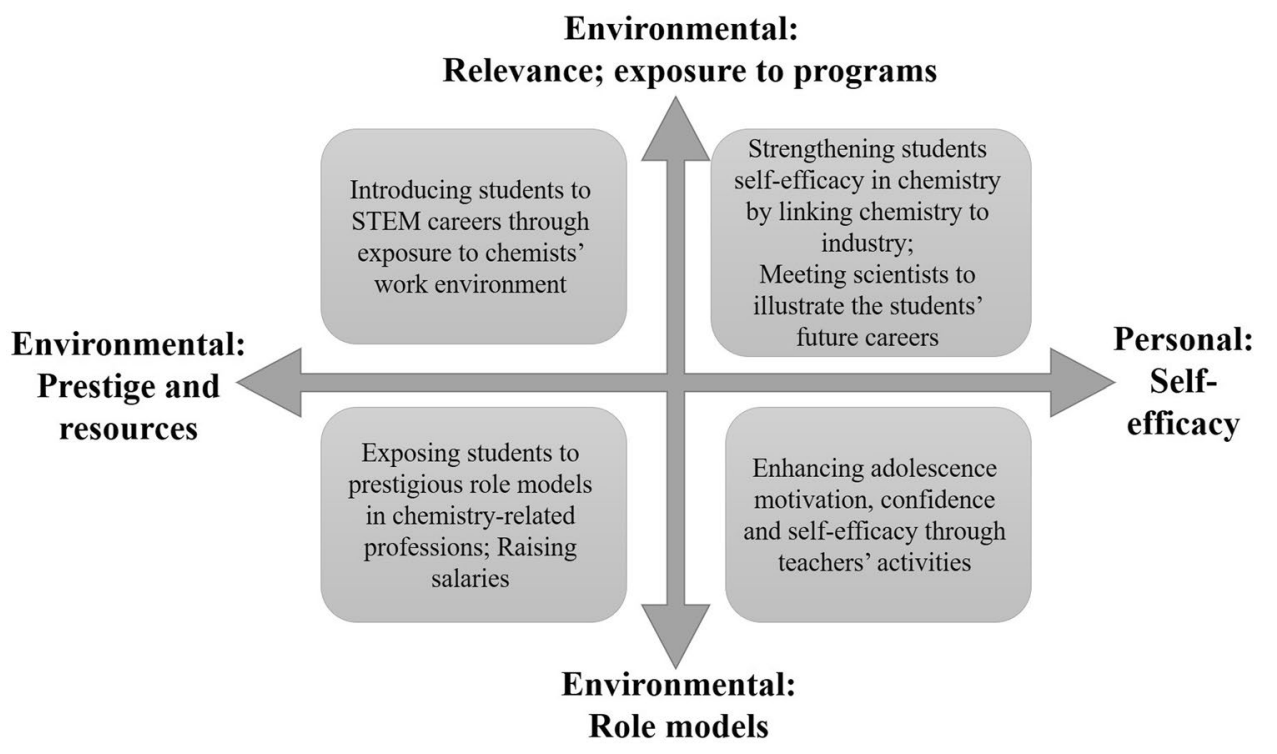


2004). As recommended by participants, raising the prestige and relevance of chemistry will motivate them to choose a chemistry related career. Overcoming and changing this perception about chemistry can be done by emphasizing the importance of chemistry by school principals, Ministry of Education, and other decision makers within the educational system at the school and national levels.

\section{Implication, Contribution, and Limitations}

CIs' and CTs' suggestion for ways to encourage students to choose a chemistry-related career as perceived by chemistry professionals might create bias. However, we believe that the strength of this population, stems from their personal experience, insights, and unique point of view, justifies considering these suggestions and using them.

We should treat the choice process as an ecosystem nurtured and enhanced by personal and environmental aspects. Revisiting the characteristics of the educational program students are exposed to during middle and high school is essential. Given this study's findings, the curriculum should include (a) diverse learning opportunities, (b) relevant content addressing everyday life phenomena, (c) linking chemistry to industry while strengthening the connection between CI and students, and (d) reference to chemistry career knowledge by encouraging students to investigate the possibility of graduate work. Figure 5 presents a conceptual model of the connection between the SCCT and interviewees' recommendations for encouraging the choice of chemistry-related careers. The model divides the plane into four quadrants, each being a combination of two categories in the environmental or personal theme and containing pertinent interviewees' recommendations.
In the personal theme, raising students' SE in chemistry can be conducted via better understanding of chemistryrelated careers and exposing them to possibilities of working in research laboratories or industries. This might lead them to defining chemistry career goals and acting on them.

Our results showed that teachers enhance the development of adolescents' motivation, confidence, and efficacy in science, leading to the pursuit of a chemistry-related career. There is a need to work towards strengthening students' self-efficacy in chemistry. At the national level, there is a need to raise the prestige of chemistry as a discipline and as a profession. These actions, which addressing the personal and environmental themes, will encourage high school students to major in chemistry. The present study is one of few studies in the field that have used the SCCT framework to examine all three aspects of career choice - personal, environmental, and behavioral, while addressing teaching and industry level. We have applied the SCCT specifically in the chemistry domain and investigated ways to foster students' self-efficacy in the context of choosing chemistry-related careers. Practically, the study provides recommendations for various stakeholders on how to encourage students to major in chemistry, later to choose chemistry-related careers, and retaining them.

\section{Appendix 1. Distribution of Choice in Chemistry and STEM Disciplines Among High School Graduates Moving to First Year of University and Graduating Bachelor's Degree During 1992-2015}

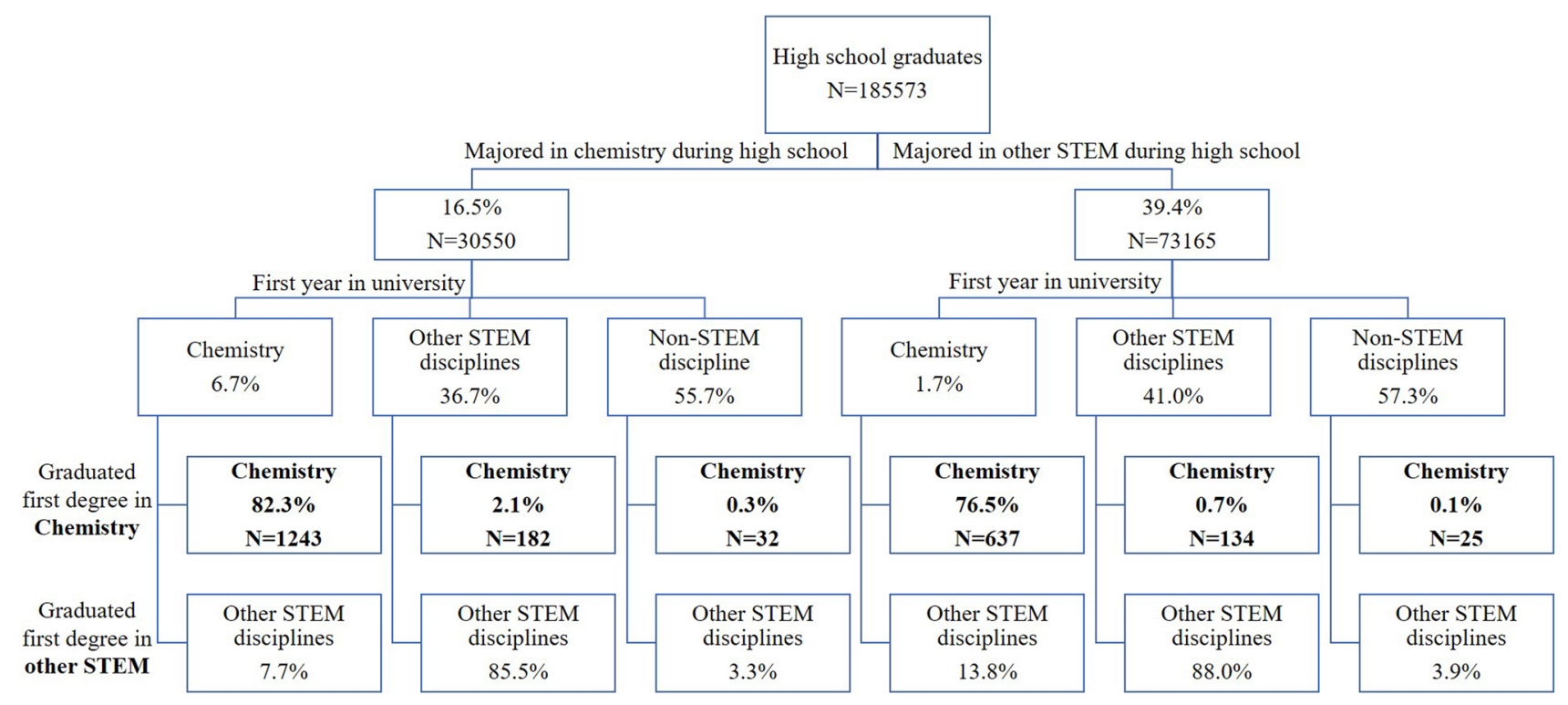




\section{Appendix 2. Distribution of Participants by Gender, Sector, and Seniority}

Table 3 Distribution of participants by gender, sector and seniority (Dori et al., 2020)

\begin{tabular}{lllll}
\hline $\begin{array}{l}\text { Research } \\
\text { group }\end{array}$ & Number & $\begin{array}{l}\text { Gender } \\
(\%)\end{array}$ & Sector (\%) & $\begin{array}{l}\text { Stage in } \\
\text { career* (\%) }\end{array}$ \\
\hline $\begin{array}{c}\text { Chemistry } \\
\text { teachers }\end{array}$ & 72 & Women 80 & Jewish 64 & Senior teachers \\
$\begin{array}{c}\text { Chemists and } \\
\text { chemical } \\
\text { engineers }\end{array}$ & 73 & $\begin{array}{l}\text { Women 56 } \\
\text { Men 44 }\end{array}$ & $\begin{array}{l}\text { Jewish 80 } \\
\text { Minorities 20 }\end{array}$ & $\begin{array}{c}\text { Senior chemist/ } \\
\text { engineers 53 }\end{array}$ \\
\hline
\end{tabular}

*Senior teachers, chemists, or chemical engineers are with more than 10 years of experience

Funding The authors received financial support from the Israel Science Foundation \#1725/16.

\section{Declarations}

Ethical Approval We received the ethical approval of the CBS Confidentiality Committee in our institutional IRB approval number 2018-034. All the participants $(N=145)$, those participants who responded to the perceptions $\mathrm{C} 3$ questionnaire, and those who were interviewed read and signed the informed consent.

Conflict of Interest We do not have anyconflict of interests.

Open Access This article is licensed under a Creative Commons Attribution 4.0 International License, which permits use, sharing, adaptation, distribution and reproduction in any medium or format, as long as you give appropriate credit to the original author(s) and the source, provide a link to the Creative Commons licence, and indicate if changes were made. The images or other third party material in this article are included in the article's Creative Commons licence, unless indicated otherwise in a credit line to the material. If material is not included in the article's Creative Commons licence and your intended use is not permitted by statutory regulation or exceeds the permitted use, you will need to obtain permission directly from the copyright holder. To view a copy of this licence, visit http://creativecommons.org/licenses/by/4.0/.

\section{References}

Alexander, P. M., Holmner, M., Lotriet, H. H., Matthee, M. C., Pieterse, H. V., Naidoo, S., \& Jordaan, D. (2011). Factors affecting career choice: Comparison between students from computer and other disciplines. Journal of Science Education and Technology, 20(3), 300-315.

Avargil, S., Kohen, Z., \& Dori, Y. J. (2020) Trends and perceptions of choosing chemistry as a major and a career. Chemistry Education Research and Practice, 21(2), 668-684

Bandura, A. (1986). The explanatory and predictive scope of selfefficacy theory. Journal of Social and Clinical Psychology, 4(3), 359-373.

Baram-Tsabari, A., \& Yarden, A. (2005). Characterizing children's spontaneous interests in science and technology. International Journal of Science Education, 27(7), 803-826.
Barnea, N., Dori, Y. J., \& Hofstein, A. (2010) Development and implementation of inquiry-based and computerized-based laboratories: Reforming high school chemistry in Israel. Chemistry Education Research and Practice, 11 (3), 218-228

Blotnicky, K. A., Franz-Odendaal, T., French, F., \& Joy, P. (2018). A study of the correlation between STEM career knowledge, mathematics self-efficacy, career interests, and career activities on the likelihood of pursuing a STEM career among middle school students. International journal of STEM education, $5(1), 22$.

Bottia, M. C., Stearns, E., Mickelson, R. A., \& Moller, S. (2018). Boosting the numbers of STEM majors? The role of high schools with a STEM program. Science Education, 102(1), 85-107.

Caspi, A., Gorsky, P., Nitzani-Hendel, R., Zacharia, Z., Rosenfeld, S., Berman, S., \& Shildhouse, B. (2019). Ninth-grade students' perceptions of the factors that led them to major in high school science, technology, engineering, and mathematics disciplines. Science Education, 103(5), 1176-1205.

Central Bureau of Statistics. (2018). Higher education in Israel. The Center for Statistics Information. (In Hebrew).

Christensen, R., \& Knezek, G. (2017). Relationship of middle school student STEM interest to career intent. Journal of Education in Science, Environment and Health, 3(1), 1-13.

Cleaves, A. (2005). The formation of science choices in secondary school. International Journal of Science Education, 27(4), 471-486.

Creswell, J.W. (2006). Choosing a mixed methods design. In Methods Design. Pp 58-89.

Dabney, K. P., Chakraverty, D., \& Tai, R. H. (2013). The association of family influence and initial interest in science. Science Education, 97(3), 395-409.

Dalgety, J., \& Coll, R. K. (2004). The influence of normative beliefs on students' enrolment choices. Research in Science \& Technological Education, 22(1), 59-80.

D'Andola, C. (2016). Women in chemistry-Where we are today. ChemistryA European Journal, 22(11), 3523-3528.

Demirdöğen, B., Hanuscin, D. L., Uzuntiryaki-Kondakci, E., \& Köseoğlu, F. (2016). Development and nature of preservice chemistry teachers' pedagogical content knowledge for nature of science. Research in Science Education, 46(4), 575-612.

Denzin, N. K., \& Lincoln, Y. S. (2000). Handbook of qualitative research (Vol. 2nd). Sage.

Diekman, A. B., \& Benson-Greenwald, T. M. (2018). Fixing STEM workforce and teacher shortages: How goal congruity can inform individuals and institutions. Policy Insights from the Behavioral and Brain Sciences, 5(1), 11-18.

Dori, Y. J., Shwartz, G. \& Shav-Artza, O. (2020). Chemistry education: Where are we headed? The Samuel Neaman Institute, Technion, Haifa, Israel, 88 pages (in Hebrew with abstract in English). https:// www.neaman.org.il/Chemistry-education-Where-are-we-headed

Dorph, R., Bathgate, M. E., Schunn, C. D., \& Cannady, M. A. (2018). When I grow up: The relationship of science learning activation to STEM career preferences. International Journal of Science Education, 40(9), 1034-1057.

Flick, U. (2018). An introduction to qualitative research. Sage Publications Limited.

Friedman, I. A. (2016). Being a teacher: Altruistic and narcissistic expectations of pre-service teachers. Teachers and Teaching, $22(5), 625-648$.

Grunert, M. L., \& Bodner, G. M. (2011). Finding fulfillment: Women's self-efficacy beliefs and career choices in chemistry. Chemistry education research and practice, 12(4), 420-426.

Hazari, Z., Potvin, G., Tai, R. H., \& Almarode, J. (2010). For the love of learning science: Connecting learning orientation and career productivity in physics and chemistry. Physical review special topics-physics education research, 6(1), 010107. 
Heinz, M. (2015). Why choose teaching? An international review of empirical studies exploring student teachers' career motivations and levels of commitment to teaching. Educational Research and Evaluation, 21(3), 258-297.

Ignatow, G. \& Mihalcea, R. (2017). Text mining. SAGE Publications, Inc. Retrieved December 2020 from: https://doi.org/10.4135/ 9781483399782

Kafetzopoulos, C., Spyrellis, N., \& Lymperopoulou-Karaliota, A. (2006). The chemistry of art and the art of chemistry. Journal of chemical education, 83(10), 1484.

Kass, E., \& Miller, E. C. (2018). Career choice among academically excellent students: Choosing teaching career as a corrective experience. Teaching and Teacher Education, 73, 90-98.

Kelly, R. R., \& Hatcher, T. (2013). Decision-making self-efficacy and barriers in career decision making among community college students. Community College Journal of Research and Practice, 37(2), 103-113.

Kniveton, B. H. (2004). The influences and motivations on which students base their choice of career. Research in Education, 72(1), 47-59.

Lechleiter, J. C. (2013). Why Chemistry Still Matters. Careers, Entrepreneurship, and Diversity: Challenges and Opportunities in the Global Chemistry Enterprisé.

Lent, R. W., Brown, S. D., \& Hackett, G. (2000). Contextual supports and barriers to career choice: A social cognitive analysis. Journal of counseling psychology, 47(1), 36.

Lent, R. W., Brown, S. D., Schmidt, J., Brenner, B., Lyons, H., \& Treistman, D. (2003). Relation of contextual supports and barriers to choose behavior in engineering majors: Test of alternative social cognitive models. Journal of Counseling Psychology, 50(4), 458.

Lent, R. W., \& Brown, S. D. (2006). On conceptualizing and assessing social cognitive constructs in career research: A measurement guide. Journal of career assessment, 14(1), 12-35.

Lent, R. W., Brown, S. D., \& Hackett, G. (2002). Social cognitive career theory. Career Choice and Development, 4, 255-311.

Lent, R. W., Brown, S. D., \& Hackett, G. (1994). Toward a unifying social cognitive theory of career and academic interest, choice, and performance. Journal of vocational behavior, 45(1), 79-122.

Magwilang, E. B. (2016). Teaching chemistry in context: Its effects on students' motivation, attitudes and achievement in chemistry. International Journal of Learning, Teaching and Educational Research, 15(4).

Mishkin, H. R., Wengrowicz, N., Dori, D, and Dori, Y. J. (2016). Career choice of undergraduate engineering students. Procedia-Social and Behavioral Sciences, 226, 222-228. https://doi. org/10.1016/j.sbspro.2016.07.033

Newell, A. D., Zientek, L. R., Tharp, B. Z., Vogt, G. L., \& Moreno, N. P. (2015). Students' attitudes toward science as predictors of gains on student content knowledge: Benefits of an after-school program. School Science and Mathematics, 115(5), 216-225.

Nugent, G., Barker, B., Welch, G., Grandgenett, N., Wu, C., \& Nelson, C. (2015). A model of factors contributing to STEM learning and career orientation. International Journal of Science Education, 37(7), 1067-1088.

Ogunde, J. C., Overton, T. L., Thompson, C. D., Mewis, R., \& Boniface, S. (2017). Beyond graduation: Motivations and career aspirations of undergraduate chemistry students. Chemistry Education Research and Practice, 18(3), 457-471.

Patton, M. Q. (1990). Qualitative evaluation and research methods. Sage.

Reinhold, S., Holzberger, D., \& Seidel, T. (2018). Encouraging a career in science: A research review of secondary schools' effects on students' STEM orientation. Studies in Science Education, 54(1), 69-103.

Richardson, P. W., \& Watt, H. M. (2016). Factors influencing teaching choice: Why do future teachers choose the career?. In International handbook of teacher education (pp. 275-304). Springer, Singapore.
Roulston, K. (2008). Conversational interviewing. Sage publications. Sahin, A., Ekmekci, A., \& Waxman, H. C. (2017). The relationships among high school STEM learning experiences, expectations, and mathematics and science efficacy and the likelihood of majoring in STEM in college. International Journal of Science Education, 39(11), 1549-1572.

Sahin, A., Gulacar, O., \& Stuessy, C. (2015). High school students' perceptions of the effects of international science Olympiad on their STEM career aspirations and twenty-first century skill development. Research in Science Education, 45(6), 785-805.

Salonen, A., Kärkkäinen, S., \& Keinonen, T. (2018). Career-related instruction promoting students' career awareness and interest towards science learning. Chemistry Education Research and Practice, 19(2), 474-483.

Salta, K., Gekos, M., Petsimeri, I., \& Koulougliotis, D. (2012). Discovering factors that influence the decision to pursue a chemistry-related career: A comparative analysis of the experiences of non scientist adults and chemistry teachers in Greece. Chemistry Education Research and Practice, 13(4), 437-446.

Sha, L., Schunn, C., Bathgate, M., \& Ben-Eliyahu, A. (2016). Families support their children's success in science learning by influencing interest and self-efficacy. Journal of Research in Science Teaching, 53(3), 450-472.

Sharf, R. S. (1992). Applying career development theory to counseling. Woodswoth.

Shekhar, P., Prince, M., Finelli, C., Demonbrun, M., \& Waters, C. (2019). Integrating quantitative and qualitative research methods to examine student resistance to active learning. European Journal of Engineering Education, 44(1-2), 6-18.

Simon, R. M., Wagner, A., \& Killion, B. (2017). Gender and choosing a STEM major in college: Femininity, masculinity, chilly climate, and occupational values. Journal of Research in Science Teaching, 54(3), 299-323.

Smith, E., \& White, P. (2019). Where do all the STEM graduates Go? Higher education, the labour market and career trajectories in the UK. Journal of Science Education and Technology, 28(1), 26-40.

Solano, D. M., Wood, F. E., \& Kurth, M. J. (2011). "Careers in chemistry": A course providing students with real-world foundations. Journal of Chemical Education, 88(10), 1376-1379.

Tal, T., \& Alkaher, I. (2010). Collaborative environmental projects in a multicultural society: Working from within separate or mutual landscapes? Cultural Studies of Science Education, 5, 325-349.

van Tuijl, C., \& van der Molen, J. H. W. (2016). Study choice and career development in STEM fields: An overview and integration of the research. International journal of technology and design education, 26(2), 159-183.

Wang, X. (2013). Why students choose STEM majors: Motivation, high school learning, and postsecondary context of support. American Educational Research Journal, 50(5), 1081-1121.

Yasin, N. Y. B. M., \& Yueying, O. (2017). Evaluating the relevance of the chemistry curriculum to the workplace: keeping tertiary education relevant. Journal of Chemical Education, 94(10), 1443-1449.

Young, J., Ortiz, N., \& Young, J. (2017). Stimulating interest: A metaanalysis of the effects of out-of-school time on student STEM interest. International Journal of Education in Mathematics, Science and Technology, 5(1), 62-74.

Ziebell, J. L. C. (2010). Promoting viable career choice goals through career decision-making self-efficacy and career maturity in innercity high school students: A test of social cognitive career theory. University of Minnesota.

Publisher's Note Springer Nature remains neutral with regard to jurisdictional claims in published maps and institutional affiliations. 